\title{
VALUE OF SHAREHOLDERS IN THE TURNAROUND PROCESS: A SigNALING THEORY PERSPECTIVE
}

\author{
Clay Dibrell \\ John Francis \\ The University of Memphis \\ Memphis, TN \\ Robert Van Ness \\ Marshall University \\ Huntington, WV
}

\begin{abstract}
This paper provides an exploratory examination of market reaction to announcements of turnaround strategies from firms involved in the turnaround process. The findings of this paper suggest the market reacts positively to announced turnaround strategies. Interestingly, nonturnaround firms posted higher positive abnormal returns than firms that eventually were able to successfully complete a turnaround.
\end{abstract}

\section{Value of Shareholders in the Turnaround Process: A Signaling Theory Perspective}

With increased competition from both domestic and global competitors, more firms are falling into continual states of decline. Once a firm recognizes it is in a prolonged cycle of decline, a turnaround process must be initiated. As managers start the turnaround process, they are faced with several difficult turnaround decisions, such as consideration of the firm's turnaround strategy on a firm's share price and stockholders. This element is a critical deliberation as shareholders contribute necessary resources to a firm (Blair, 1995), and their commitment to the turnaround strategy is vital to its ultimate success.

While previous turnaround research has focused on industry characteristics, types of decline, and differing types of turnaround strategy (Hambrick \& Schecter, 1983; Schendel \& Patton, 1976), the relationship between a firm's turnaround strategy and its shareholders has not been examined. The significance of shareholders lies not only in contributing financial resources to the declining firm but in providing signals to managers regarding the appropriateness of an announced turnaround strategy. Signaling theory suggests that shareholders, through the market, provide signals to management concerning the impact of an announced strategy upon the future value of the firm (Agrawal \& Kamakura, 1995; Gilson, 1990; Lane \& Jacobson, 1995; Rappaport, 1987; Sutton \& Callahan, 1987). For example, if the market reacts with an abnor- 
mally high return to an announced strategy, then the market sends a positive signal of the announced strategy to the manager (Agrawal \& Kamakura, 1995; Lane \& Jacobson, 1995; Rappaport, 1987). This feedback is even more critical for firms in a prolonged decline which are attempting to regain creditability with employees, shareholders, creditors, and customers.

With the paucity of empirical research concerning the significance of the shareholder in the turnaround process, the primary purpose of this paper is to examine how the market responds to an announcement of a turnaround strategy. The secondary purpose is to study whether the market signals nonturnaround firms more positively than turnaround firms. This paper attempts to answer these questions through an event study of publicly traded firms that have undergone decline and have announced a turnaround strategy. The sample includes firms that were eventually able to turnaround (i.e., turnaround firms) during the sample period and those that either failed or continued to perform poorly (i.e., nonturnaround firms) during the sample period. The first section of this paper consists of a brief, relevant literature review of the turnaround literature and application of signaling theory to the turnaround literature. Then, the paper formulates hypotheses that reflect shareholder perceptions of a declining firm's turnaround strategy. The testing of these hypotheses is then provided through an event study of the relationship between a firm's announced turnaround strategy and the market. Lastly, the paper concludes with a discussion and summary of the results.

\section{Literature Review}

In order to examine the market's response to turnaround actions, it is necessary to identify types of turnaround strategies that firms undertake in order to reverse decline. One method of organizing the numerous types of strategies is by classifying them as either operational or strategic (Hofer, 1980). Operational turnaround strategies involve increasing revenues, decreasing costs, decreasing assets, or a mixture of these actions. Strategic turnaround strategies includes such actions as acquisitions, vertical integration, diversification, divestment, and top management changes. The distinguishing difference between these two types of turnaround strategies is that operational turnaround strategies are more tactical in nature (Hofer, 1980), whereas strategic actions take place at the corporate level and alter a firm's structure and possibly its core competencies (Arogyaswamy, Barker \& Yasai-Ardekani, 1995; Barker \& Duhaime, 1997; Hofer, 1980).

Operational turnaround strategies focus upon a firm becoming more efficient through asset and cost reduction (Pearce \& Robbins, 1993, 1994; Robbins \& Pearce, 1992; Slater, 1984) where by performance targets are the key to operational strategies (Barker, 1992; Hofer, 1980). There is a variety of cost-cutting methods in this set of turnaround strategies that includes plant closings, reduction of overhead, dropping of product lines, and layoffs (Bibeault, 1982; Finkin, 1987; Pearce \& Robbins, 1993, 1994; Robbins \& Pearce, 1992). 
A strategic turnaround differs from an operational reorientation as it implies a change of a firm's strategy (Arogyaswamy, Barker \& Yasai-Ardekani, 1995; Barker \& Duhaime, 1997; Hofer, 1980). A strategic turnaround is built on core competencies or key skills of functional areas (Barker, 1992; Hofer, 1980). A change of a firm's strategy can come in the form of either acquisition, divestiture, or CEO replacement (Barker \& Duhaime, 1997; Hofer, 1980). In keeping with these arguments, a coarse-grained approach is needed for this exploratory inquiry. This paper takes a perspective that both operational and turnaround strategies should be grouped together to allow for an exploratory understanding of how the market reacts to all turnaround strategies.

Another consistent finding of the turnaround literature is the need for slack resources to implement a turnaround strategy (Hofer, 1980; D'Aveni, 1989; Robbins \& Pearce, 1992; Arogyaswamy, Barker \& Yasai-Ardekani, 1995). If a firm has a scarcity of slack resources, it will further constrain a manager's efforts to successfully implement a turnaround strategy (Hofer, 1980; D’Aveni, 1989; Robbins \& Pearce, 1992). Argogyaswamy, Barker \& Yasai-Ardekani (1995) postulate that a firm's probability for a turnaround is correlated with the amount of slack that a firm possesses. If a firm does not have adequate slack resources to implement a turnaround strategy, then a firm is forced to generate slack in order to effectively implement a turnaround strategy.

Arogyaswamy, Barker \& Yasai-Ardekani (1995) suggest that the demand for the generation of slack resources is related to the perception of shareholders. Positive signals from management during the turnaround process are essential to maintain and to generate shareholder support (Castrogiovanni, Balig \& Kidwell, 1992). Therefore, managers must understand the significance of implementing strategies that shareholders believe will create a positive future value for a firm. If shareholders do not believe that the management of a declining firm is implementing an appropriate turnaround strategy, then shareholders will signal the firm's management with an abnormally negative market reaction (Agrawal \& Kamakura, 1995; Lane \& Jacobson, 1995; Rappaport, 1987).

The basis of signaling theory is a product of the research examining how the market reacts to announcements surrounding a firm's dividends (Michaely \& Shaw, 1994; Miller \& Rock, 1985; Rock, 1986). This literature suggests that a firm which announces that it will either be increasing or reducing dividends sends a signal to the market. If a firm is increasing its dividends, this signals the market that a firm believes that it will be able to justify the increased dividends through immediate future positive growth. If the market believes the dividends justify an increase in the future value of a firm, then the market will react positively.

This same argument has been extended in the work of Rappaport (1987) to include non-dividend stock announcements. Market expectations of a firm can be reflected in a firm's stock price (Rappaport, 1987). Rappaport postulates that managers can receive immediate feedback from the market concerning a firm's strategy. Moreover, managers have the opportunity to determine if their strategies 
will be appropriate through the response of the market. If the market provides a negative response to a proposed activity, then managers should reevaluate their strategy. Conversely, if a firm's stock price has a positive abnormal return, then the market expects the immediate future value of a firm will increase. In effect, the market's reaction to a firm's announced strategy acts as a proxy of the market's expectations to the firm's announced strategy.

Therefore, managers must understand the significance of implementing turnaround strategies that shareholders believe will create an immediate positive future value for a firm. From a signaling theory perspective, it can be argued that nonturnaround firms could have a higher abnormal return than turnaround firms. The basis for this assessment is that the potential for growth for a nonturnaround firm that is continually in a state of decline is greater than for a firm that is completing a turnaround. For example, one nonturnaround firm has had increasing decline but makes a drastic reduction in net losses, while a turnaround firm is slowly and steadily growing toward profitability. The nonturnaround firm stems decline from a $200 \%$ annual loss to a $50 \%$ annual loss for the next time period through implementation of a turnaround strategy with a net positive gain of $150 \%$. Compare this scenario to the turnaround firm that continues to grow from a $7 \%$ annual loss to a $3 \%$ positive annual growth after implementing a turnaround strategy for the next time period with a net gain of $10 \%$. Where is the greatest net growth for the second time period? The greatest net growth for the second time period comes from the nonturnaround firm whose net gain is $150 \%$, as compared to a $10 \%$ net gain for the turnaround firm. In this case, the market could provide an immediate higher abnormal return to the nonturnaround firm. This argument is further supported by the belief that an action taken by management which increases the immediate value of the firm should result in positive signals from the market (Agrawal \& Kamakura, 1995; Lane \& Jacobson, 1995; Rappaport, 1987).

\section{Hypotheses}

Arogyaswamy, Barker \& Yasai-Ardekani (1995) suggest that renewed shareholder support should be a primary consideration of management involved in the turnaround process. Renewed shareholder support comes in several forms, including generating slack and access to capital needed for the implementation of a turnaround strategy. One possible way to generate these resources is through announcing a turnaround strategy that shareholders believe will increase the future value of a firm (Davidson, Worrell \& El-Jelly, 1995). A turnaround strategy implies that a firm implements some form of a strategy in order to regain a state of profitability (Barker, 1992). In essence, a turnaround strategy attempts to create a future value for a firm. The market is based upon future values of firms (Hoskisson, Johnson \& Moesel, 1994; Hoskisson, Hitt \& Hill, 1993; Jacobson, 1987); and 
shareholders will reward firms for attempting to generate greater immediate future value. Based on this discussion, the following hypothesis is offered:

Hypothesis 1: The market provides immediate abnormal positive returns for firms that announce a turnaround strategy.

Signaling theory suggests that the market provides feedback to a manager's strategy through positive or negative reactions to an announcement (Agrawal \& Kamakura, 1995; Gilson, 1990; Lane \& Jacobson, 1995; Rappaport, 1987). A positive reaction by the market will suggest that a firm is implementing an appropriate turnaround strategy (Chatterjee, Dhillon \& Ramirez, 1996; Davidson, Worrell \& El-Jelly, 1995). Furthermore, nonturnaround firms will exhibit immediate higher abnormal returns than firms that eventually turnaround. For example, a continually failing firm announces to the market that it will be implementing a turnaround strategy that involves divesting an unprofitable strategic business unit. The market should react positively to the announcement and the possibility of a higher return once the unprofitable strategic business unit is unloaded. However, a turnaround firm that announces a turnaround strategy could possibly not have as a great return, as compared to the nonturnaround firm, since the potential for future short-term growth may be limited as the turnaround firm approaches profitability. This scenario, though, does not consider the long-term value of the announced turnaround strategy, only the immediate reaction of the market to the announced turnaround strategy. Moreover, the market could be signaling the nonturnaround firm to continue to implement turnaround strategies. Thus, the following hypothesis is offered:

Hypothesis 2: The market reacts more positively to an announcement of a turnaround strategy by a nonturnaround firm than a firm that eventually completes a turnaround on the day of the announcement of a turnaround strategy.

\section{Methodology}

\section{Sample}

For a sampling of firms involved in the turnaround process, there has been a great deal of discussion regarding the most appropriate way to measure decline (Arogyaswamy, Barker \& Yasai-Ardekani, 1995; Barker, 1992; Barker \& Duhaime, 1997; Robbins \& Pearce, 1992). In order for this sample to reflect firms involved in a turnaround situation, several different conservative criteria were employed. The following performance criteria were utilized in order to determine declining firms:

1. Initially a firm had to have at least two consecutive years of ROI above the risk-free rate of return (Barker \& Mone, 1994; Robbins \& 
Pearce, 1992). The return rate for six month US treasury notes at auction, reported in the Economic Report for the President, is used as a proxy for the risk-free rate. This criterion is included because it eliminates firms from the sample that continue to fail which limits the study to firms that face a turnaround process. The risk-free rate of return was used as a criterion based on Porter's (1980) argument that a firm is failing in economic terms if it does not earn a return greater than the risk-free rate. Furthermore, this measure provides a rigorous technique of examining financial performance of a cross section of firms (Hansen \& Wernerfelt, 1989).

2. Each firm had to have at least 3 consecutive years of decline below the risk-free rate of return. Also, at least one year within three years of decline had to be characterized by a negative net income (Barker \& Duhaime, 1997).

3. Lastly, turnaround was characterized by two consecutive years of ROI above the risk-free rate (Robbins \& Pearce, 1992). Nonturnaround firms will not achieve this performance recovery; however, data for these firms are gathered for this time-frame based on the three to four year average time for a successful turnaround (Robbins \& Pearce, 1992). Thus, turnaround performance is measured in terms of whether a firm is or is not able to recover within the time span of the data collection period.

Researchers have been critical of the small sample sizes that previous researchers have utilized when employing event studies (McWilliams \& Siegel, 1997). To guard against a small sample, the sample was selected from manufacturing firms operating within the two digit SIC groups (20-39) for two reasons. First, a sample taken within an industry that meets the turnaround criteria set forth would be too small, while going across industries provides for a larger sample size. Secondly, the generalizability of the findings from this study will be en hanced with the sample being taken across manufacturing industries. The time frame of the sample covers the fiscal years 1980 through 1992, allowing sample firms a suitable amount of time for performance declines and strategic responses. Lastly, the financial data was gathered through the COMPUSTAT II data repository.

Due to the exploratory nature of the study, both operational and strategic orientation turnaround strategies are grouped together. For a strategy to be identified as a turnaround strategy, an announcement must consist of one of the four turnaround strategies: 1) asset reduction; 2) acquisition; 3) change of CEO; and 4) divestiture. The asset reduction category includes announcements of layoffs, plant closings, and reduction of costs as suggested in the literature (Hofer, 1980; Pearce \& Robbins, 1993, 1994; Robbins \& Pearce, 1992; Slater, 1984). The CEO replacement category includes all CEO changes during the period of decline to 
account for officers that are forced to resign. Furthermore, the following criteria are used in conjunction with the turnaround sample criteria.

1. Since the daily stock data came from the Center for Research in Security Prices (CRSP), firms must be traded on either the New York Stock Exchange or the American Stock Exchange.

2. No two turnaround events can overlap within 175 days before the event and 50 days after the event.

3. If turnaround events did crossover, then the events are eliminated from the study.

4. Multiple turnaround event announcements eliminate all turnaround event announcements for that time period regardless of categorization.

5. All turnaround event dates are from the Wall Street Journal.

For the event study analyses, precise identification of the actual date of each turnaround announcement is a strong consideration. Since an event announcement can be leaked to the public through a variety of sources before the event date appears in the Wall Street Journal, we employed a 2-day event window to correctly identify when the market reacted to the announcement. The Wall Street Joumal index identifies the date of the announcement, but the market may have reacted to the announcement prior to the posting. For example, the announcement is given to the Wall Street Journal the day before it goes to press. Thus, it is possible that the announcement could be leaked. In order to capture these announcement effects, we used both the day that the Wall Street Journal index provides and the prior day to ensure that the 2-day event window adequately captures the reaction to the announcement (McWilliams \& Siegel, 1997; Szewczyk, Tsetsekos \& Zantout, 1996; Tsetsekos \& Gombola, 1992). From the criteria, 137 firms were selected. Of these firms, 58 successfully completed the turnaround process, while 79 continued to fail.

\section{Method}

An event study methodology was chosen to measure the market's reaction to a firm-specific announcement. This methodology has been suggested to be an appropriate statistical technique to measure the reaction of the market to an announcement of a firm-specific event (Brown and Warner, 1980, 1985).

To control for the potential for nonsynchronous trading problems of firms of differing liquidity to influence the empirical results, the ScholesWilliams (1977) market model is employed to estimate the intercept and slope coefficients used in the generation of the expected daily returns for each firm in the absence of a turnaround announcement. Specifically, intercept and slope coefficients used in the generation of the expected daily returns for each firm $j, \alpha j$ and $\beta j$, respectively, are estimated for the 150 day 
period (event days $t=-175 \ldots-26)$ prior to the event window period (event days $t=-25 \ldots+50)$ and are defined as

$$
\alpha j=1 / 98 \sum_{t=-174}^{-26} \mathrm{Rjt}-1 / 98 \beta j \sum_{\mathrm{t}=-174}^{-26} \mathrm{Rmt}
$$

where $R j t$ is the actual equity return on firm $j$ for event day $t, R m t$ is the actual return on the value-weighted CRSP index for day $t$, and

$$
\beta \mathrm{j}=(\dot{\beta j}+\stackrel{0}{\beta} \mathrm{j}+\stackrel{+}{\beta \mathrm{j}}) /(1+2 \rho \mathrm{m})
$$

In equation (2), $\rho \mathrm{m}$ is the estimated first order autocorrelation coefficient of the CRSP index over the period $t=-175 \ldots-26$, and the individual beta terms are ordinary least squares regression coefficients estimated from the following three equations:

$$
\begin{aligned}
& R j t=\alpha j+\beta j R m t-1+u j t, \quad t=-174, \ldots,-26, \\
& 00 \\
& \operatorname{Rj} t=\alpha j+\beta j R m t-1+v j t \quad t=-175, \ldots,-26 \text {, } \\
& R j t=\alpha j+\beta j R m t-1+w j t, \quad t=-175, \ldots,-27 \text {. }
\end{aligned}
$$

To detect abnormal firm returns in response to a turnaround announcement, a standard market-model event-time methodology is employed. Thus, the abnormal return for firm $\mathrm{j}$ for event day $\mathrm{t}(\mathrm{t}=-25 \ldots+50), \mathrm{ARjt}$, is defined as in equation 6:

$$
\operatorname{ARjt}=\operatorname{Rjt}-(\alpha j+\beta j \mathrm{Rmt})
$$

where $\alpha \mathrm{j}$ and, $\beta \mathrm{j}$ are the Scholes-Williams (1977) market-model parameters, and Rjt and Rmt are as previously defined above.

Lastly, to test for abnormal returns a t-test is employed between the expected daily returns and the actual returns for the event days examined. The critical value is derived from the Student's $t$ distribution tables for a two-tailed test at the $(p<.05)$ level of significance. 


\section{Results}

The results of the analyses are presented in two tables. Table 1 contains turnaround firms, and Table 2 contains the sample of nonturnaround firms. For the total sample of firms contained in both tables, Hypothesis 1 is supported. Firms that announced turnaround strategies enjoyed positive abnormal returns on the day of the announcement. For example, in Table 1, turnaround firms are significantly abnormal through the standardized $t$-test statistic $(t)$. At the $(p<.05)$ level of significance with the critical $t$-value of 1.960 , the market reacts positively $(\mu=.0176 ; t=3.0795)$ for firms announcing a turnaround strategy during the two-day event window.

Table 1

Mean Daily Abnormal Return Results and Test Statistics for Turnaround Firms $(n=58)$.

\begin{tabular}{ccc}
\hline Event Day & $\begin{array}{c}\text { Mean Daily } \\
\text { Abnormal Return }\end{array}$ & Test Statistic \\
\hline-25 & -0.0010 & -0.1812 \\
-15 & -0.0012 & -0.2120 \\
-5 & 0.0013 & 0.2339 \\
-4 & 0.0073 & 1.2907 \\
-3 & -0.0004 & -0.0726 \\
-2 & -0.0042 & -0.7370 \\
-1 & -0.0096 & -1.6821 \\
& & \\
0 & 0.0176 & $3.0795 *$ \\
2 & 0.0050 & 0.8832 \\
3 & 0.0067 & 1.1754 \\
4 & 0.0066 & 1.1531 \\
5 & 0.0086 & 1.5026 \\
15 & 0.0032 & 0.5732 \\
25 & 0.0008 & 0.1463 \\
50 & 0.0018 & 0.3265 \\
\hline
\end{tabular}

${ }^{*} \mathrm{p}<.05$ 
For continually failing firms in Table 2, the stock market reacts positively to announcements of turnaround strategies. There is a strong positive abnormal return for failing firms $(\mu=.0172 ; t=3.3086)$ announcing a turnaround strategy at the $(p<.05)$ level of significance.

Table 2

Mean Daily Abnormal Return Results and Test Statistic for Nonturnaround Firms $(n=79)$.

\begin{tabular}{ccc}
\hline Event Day & $\begin{array}{c}\text { Mean Daily } \\
\text { Abnormal Return }\end{array}$ & Test Statistic \\
\hline-25 & -0.0049 & -0.9349 \\
-15 & -0.0077 & -1.4807 \\
-5 & 0.0013 & \\
-4 & 0.0006 & 0.2394 \\
-3 & -0.0028 & 0.1134 \\
-2 & 0.0055 & -0.5287 \\
-1 & -0.0025 & 1.0642 \\
& & -0.4841 \\
0 & 0.0172 & $3.3086 *$ \\
2 & 0.0072 & 1.3759 \\
3 & -0.0048 & -0.9181 \\
4 & 0.0066 & 1.2587 \\
5 & -0.0031 & -0.5869 \\
15 & -0.0036 & -0.6860 \\
25 & 0.0046 & 0.8850 \\
50 & 0.0037 & 0.7083 \\
\hline
\end{tabular}

${ }^{*} \mathrm{p}<.05$

Comparison between turnaround and nonturnaround firms demonstrates that the stock market reacts statistically more favorably to nonturnaround firms than to turnaround firms. Overall, the market's reaction to the future value of both classifications of firms is abnormally positive. These results support hypothesis 2 , which suggested that the market would react more favorably to the announcements of a turnaround strategy for nonturnaround firms than for turnaround firms. 


\section{Discussion and Conclusion}

This paper attempted to explore the relationship between turnaround and nonturnaround firms and how the market reacts to a turnaround strategy. The paper tested the applicability of signaling theory to the turnaround process. Interestingly, the findings of this paper suggest any announcement of a turnaround strategy provides a firm with an abnormal positive return on the day of the announcement, regardless of whether a firm successfully completes a turnaround or continues to fail. Hypothesis 1 proposed that firms implementing any type of turnaround strategy should gain positive abnormal returns from the market and was supported. Moreover, this finding could infer that firms which continued to fail were limiting shareholder losses through turnaround strategies. In addition, findings suggest that the market provides a stronger immediate positive return for firms that are failing. The support for Hypothesis 2 suggests that managers of a firm in a turnaround process can look to the market for feedback regarding turnaround strategies. These announcements could generate immediate abnormal positive returns as the market reacts positively to firms that are stemming losses and creating wealth for the shareholders. This finding is consistent with signaling theory as the market reacts positively to firms that are creating shareholder wealth or potentially limiting shareholder losses by creating greater value for nonturnaround firms through turnaround strategies.

From the findings, it can be argued that the market could consider the amount of risk involved and determine that more opportunities exist for short-term returns from adjustments as nonturnaround firms take actions to halt decline. The most interesting finding is that the market reacted more positively to nonturnaround firms than to turnaround firms. From this finding it can be inferred that on the day of the announcement, firms that are continually failing provide greater future value to shareholders than firms that are eventually able to turnaround. However, these findings do have limitations.

One limitation of this paper is the original nature of this research. The lack of other studies to guide the research of market reactions to turnaround announcements limits the examination to a more exploratory nature. Furthermore, the different types of turnaround strategies are not compared within the different strategic turnaround categories (e.g., operational versus strategic orientation); they are compared only at an aggregate level between firms that successfully completed a turnaround and those that continued to fail. The type of a turnaround strategy could have an effect upon the reaction of the market. Another limitation of this study is that there is no differentiation between the types of shareholders (e.g., institutional and blockholders) which could influence the impact of the announcement (Wright, Ferris, Sarin \& Awasthi, 1996).

The objective of this paper was to provide an exploratory examination of the turnaround process from a market perspective. From this research, the findings provide fertile ground for future research. The different types of turnaround strat- 
egies can be examined individually between the different classifications (e.g., operational versus strategic oriented turnaround strategies) to indicate if the market consistently rewards one type of turnaround strategy over another. Also, an agency theory perspective may further illuminate the relationship between the actions of shareholders and management.

A practical implication for managers is that the market reacts positively to an announcement of a turnaround strategy. Thus, managers should be more willing to attempt and to announce a turnaround strategy. The market's positive reaction to turnaround strategies should signal managers that attempting and implementing turnaround strategies is one potential way to generate increased slack resources. In addition, it provides an opportunity to gain creditability with shareholders through increased shareholder wealth.

In conclusion, this paper attempted to examine the relationship between the market and firms involved in the turnaround process. The results of the study suggest that the market positively encourages a firm for implementing a turnaround strategy and rewards nonturnaround firms more positively than turnaround firms on the day of the announcement. Finally, this paper examined the turnaround process from an alternative perspective, from the viewpoint of the market. This perspective contributes to a richer understanding of the turnaround process.

\section{References}

Agrawal, J., \& Kamakura, W.A. (1995). The economic worth of celebrity endorsers: An event study analysis. Journal of Marketing. 59, 56-62.

Arogyaswamy, K., Barker, V.L., III, \& Yasai-Ardekani, M. (1995). Firm turnarounds: An integrative two-stage model. Journal of Management Studies. 32, 493-525.

Barker, V.L., III. (1992). Corporate turnarounds as strategic reorientations: A field study of turnaround attempts from firm-based decline. Unpublished doctoral dissertation, University of Illinois at Urbana-Champaign.

Barker, V.L., III., \& Duhaime, I.M. (1997). Strategic change in the turnaround process: Theory and empirical evidence. Strategic Management Journal. 18, 13-38.

Barker, V.L., III., \& Mone, M.A. (1994). Retrenchment: Cause of turnaround or consequence of decline. Strategic Management Journal. 15, 395-405.

Bibeault, D. (1982). Corporate turnaround, New York: McGraw-Hill.

Blair, M.M. (1995) Ownership and control: Rethinking corporate governance for the twenty-first century. The Brooking Institute.

Brown, S.J., \& Warner, J.B. (1980). Measuring security price performance. Journal of Financial Economics. 8, 205-258. 
Brown, S.J., \& Warner, J.B. (1985). Using daily stock returns: The case of event studies. Journal of Financial Economics. 14, 3-31.

Castrogiovanni, G.J., Baliga, B.R., \& Kidwell, R.E., Jr. (1992). Curing sick businesses: Changing CEOs in turnaround efforts. Academy of Management Executive, 6, 2641 .

Chatterjee, S., Dhillon, U.S., \& Ramirez, G.G. (1996). Resolution of financial distress: Debt restructuring via Chapter 11, prepackaged bankruptcies, and workouts. Einancial Management. 25, 5-18.

D'Aveni, R. (1989). The aftermath of organizational decline: A longitudinal study of the strategic and managerial characteristics of declining firms. Academy of Management Journal. 32, 577-605.

Davidson, W.N., III, Worrell, D.L., \& El-Jelly, A. (1995). Influencing managers to change unpopular corporate behavior through boycotts and divestitures: A stock market test. Business and Society. 34, 2: 171-196.

Finkin, E.F. (1987). Successful corporate turnarounds: A guide for board members, financial managers. financial institutions. and other creditors. New York: Quorum Books.

Gilson, S.C. (1990). Bankruptcy, boards, banks, and blockholders: Evidence on changes in corporate ownership and control when firms default. Journal of Financial Economics, 25, 355-387.

Hambrick, D.C., \& Schecter, S.M. (1983). Turnaround strategies for mature industrialproduct business units. Academy of Management Journal. 26, 231-248.

Hansen, G.S., \& Wernerfelt, B. (1989). Determinants of firm performance: The relative importance of economic and organizational factors. Strategic Management Journal. $10,399-411$.

Hofer, C.W. (1980). Turnaround strategies. Journal of Business Strategy 1, 1: 19-31.

Hoskisson, R.E., Johnson, R.A., \& Moesel, D.D. (1994). Corporate divestiture intensity in restructuring firms: Effects of governance, strategy, and performance. Academy of Management Journal, 37, 1207-1251.

Hoskisson, R.E., Hitt, M.A., \& Hill, C.W. (1993). Managerial incentives and investment in R\&D in large multi-product firms. Organization Science, 4, 325-341.

Jacobson, R. (1987). The validity of ROI as a measure of business performance. American Economic Review, 77, 470-478.

Lane, V., \& Jacobson, R. (1995). Stock market reactions to brand extension announcements: The effects of brand attitude and familiarity. Journal of Marketing 59, 63-77. 
McWilliams, A., \& Siegel, D. (1997). Event studies in management research: Theoretical and empirical issues. Academy of Management Journal, 40, 626-657.

Michaely, R., \& Shaw, W.H. (1994). The pricing of initial public offerings: Tests of the adverse selection and signaling theories. Review of Financial Studies. 7, 279-320.

Miller, M.H., \& Rock, K. (1985). Dividend policy under asymmetric information. Journal of Finance, 40, 1031-1051.

Pearce, J.A., II., \& Robbins, D.K. (1993). Toward improved theory and research on business turnaround. Journal of Management. 19, 613-636.

Pearce J.A., II., \& Robbins, D.K. (1994). Retrenchment remains the foundation of business turnaround. Strategic Management Journal. 15, 407-417.

Porter, M. (1980). Competitive strategy. New York: The Free Press.

Rappaport, A. (1987). Stock market signals to managers. Harvard Business Review. 65, 6: 57-62.

Robbins, D.K., \& Pearce, J.A., II. (1992). Turnaround: Retrenchment and recovery. Strategic Management Journal. 13, 287-309.

Rock, K. (1986). Why new issues are underprices. Journal of Financial Economics, 15. $187-212$.

Scholes, M.S. \& Williams, J.T. (1977). Estimating betas from nonsynchronous data. Journal of Financial Economics. 5, 309-327.

Schendel, D.E., \& Patton, G.R. (1976). Corporate stagnation and turnaround. Journal of Economics and Business. 28, 236-241.

Slater, S. (1984). Corporate recovery: Successful turnaround strategies and their implementation. Singapore: Penguin Books.

Sutton, R.I., \& Callahan, A.L. (1987). The stigma of bankruptcy: Spoiled organizational image and its management. Academy of Management Journal. 30, 405-436.

Szewczyk, S.H., Tsetsekos, G.P, \& Zantout, Z. (1996). The valuation of corporate R\&D expenditures: Evidence from investment opportunities and free cash flow. Financial Management. 25, 105-110.

Tsetsekos, G.P., \& Gombola, M.J. (1992). Foreign and domestic divestments: Evidence on valuation effects of plant closings. Journal of International Business Studies. 23, 203-223. 
Wright, P., Ferris, S.P., Sarin, A., \& Awasthi, V. (1996). Impact of corporate insider, blockholder, and institutional equity ownership on firm risk taking. Academy of Management Journal, 39, 441-463.

Clay Dibrell is currently completing his Ph.D. degree in strategic management at The University of Memphis. His current research interests include corporate diversification, influence of information technology upon firm competitiveness, and international strategy.

John Francis is an Instructor of Management in the Fogelman College of Business and Economics at The University of Memphis. He received an M.B.A. from Samford University and is currently working on his dissertation at the University of Memphis. His research interests include strategic and international management, with particular emphasis on international entrepreneurship and born global firms.

Robert A. Van Ness is an Assistant Professor of Finance at Marshall University. He received his Ph.D. in finance from The University of Memphis. His current research interests include investments and market microstructure. 